\title{
THE DISCOURSE OF "LOCAL" IN MODERN CULTURAL KNOWLEDGE: CONCEPTS AND RESEARCH STRATEGIES
}

\section{Vytkalov Sergiy}

\section{INTRODUCTION}

Introduction. To understand the logic of forming a specific cultural map, without which it is impossible to talk about the complete history of national culture, it requires its synthetic reconstruction as a unique integrity based on the analysis of the variety of spatial loci of human being. Therefore, spatial discourse in the context of contemporary cultural studies is defined by the search for a "new locality" as ways of constructing a cultural map of processes and phenomena, which are actively changing and transforming.

The works of leading western researchers, whose subject of attention are such concepts as "cultural area", "region", "local cultural practices", "production of cultural area", etc. are analyzed. The corresponding research methods of these authors were identified and an attempt was made to impose these techniques on Western Ukrainian cultural reality. The importance of local history study is emphasized both in the life of each state and in cultural studies. The local histories influence the formation of national discourse.

This work is a kind of methodological basis for many scientific works of the author aimed at the study of the regional cultural and artistic area.

\section{Features of the cultural area study in the context of globalization factors: methodological aspect of modeling}

In the contemporary native and foreign cultural studies, the discursive field of local cultures is more and more actively being formed. Local area (region, city, street), local text, local identification - these theoretical constants activate the research vector toward the place and space definition of cultural phenomena and processes. The culture of place, topus, locus in the context of topological reflection (V. Savchuk) is a reaction to the global, multicultural, postcolonial spatial compression of present. Almost antinomic contrasts of "Global World" - "Big Village", "Center" - "Periphery", "Capital" - "Province", "Native" - "Foreign" mark new models of correlation both within individual culture and openness of intercultural interaction. Globalization challenges encourage the construction of new senses in understanding of cultural features of temporal and spatial certainty and the identification of senses of local self-sufficiency. According to a French philosopher and poststructuralist M. Foucault, "Present can be called the era 
of space" [4]. Accordingly, "new locality", "new spatial logic" (M. Castels), "other spaces" (M. Foucault) ${ }^{1}$ of non-classical humanities produce theories of local cultures as models of cultural certainty in uncertain global chaos, total globalization increases the tendency for cultural variability and diversity.

The rejection of meta-narratives as an actual principle of constructing a modern discursive field of humanities influenced the change of perspectives in the study of culture from the standpoint of its topological constants. Such structural components of cultural isolation as locus, topos, region in the plane of discourse (unlike the metanarratives of immersed classical hierarchies of culture) create a model of a new ontology - the ontology of place.

The directions of vectors "from central culture to regional", "from national to local", "from global to glocal" are changing to the opposite. Accordingly, the gathering of cultural senses is concentrated in locality.

It is clear that, from the standpoint of the global meta-narrative, many distinctive cultural loci at first glance seem to be a chaotic panorama-collage of local peculiarities, which are sealed and hidden from third-party or otherwise. It is known that each cultural region is unique in view of the natural and climatic, psychophysiological, social and cultural features; that directly affects the features of identity and peculiarities - and this is an upstream principle in understanding of cultural locality. However, from these fundamental definitions, the discourse of cultural loci is only beginning. For example, the peculiarity of the formation of Ukrainian local contexts can be defined as anti-colonial discourse in search of new cultural boundaries. Accordingly, each cultural region within Ukraine has its own historical and cultural dynamics of local discourse creation. Symbols, emblems, monuments, traditions, archetypes, myths, folklore of individual cultural loci are formed in the process of cultural formation, unificating or, on the contrary, stratifycating - and this is a constant process.

Consider that historically and politically defined borders of regions do not coincide with cultural loci: cultural boundaries are formed by complex structural differences - natural, racial, linguistic, religious and confessional, etc. Accordingly, frontier (frontal) synergies make cross-sections between regions transparent. In the frontal mobility of cultural cross-borders, there is a need to create a new model of spatial typology, which would refuse to reduce the reduction of parts of the structure into an already predetermined hierarchical model. Modern cultural science produces discursive planes for the application of spatial dimensions of culture - cultural area, mental space, locus, local cultural text, place culture, chrono/topos. In the context of a nonclassical methodology, cultural studies of the locus of culture are always interdisciplinary studies, which are based on the following principles:

${ }^{1}$ М. Фуко Режим доступу: https://uk.wikipedia.org/wiki/ Мішель_Фуко 
- the principle of atomic locality of all structural elements of the cultural locus (the cultural locus is not reduced by general meanings of the whole, the Center);

- the principle of the diversity of forms of spatial human being, in which cultural practices and institutions are regarded as spatial loci for the formation of cultural identities;

- the principle of boundary (the boundary of local cultures is not determined by political and geographical boundaries, but is an ontological and ideological constant).

Therefore, it is necessary to clearly define the conceptual principles of "local" cultural studies, to formulate a categorical and conceptual apparatus for exploration of local cultures, and to direct this methodology to the practical plane of research - from the point of view of local projection to reveal the features of cultural formation of Western Polissya in the aspect of cultural and artistic activity. This approach allows us to formulate unique characteristics of individual spatial locations within national culture and to create a theoretical model for predicting further strategies for the formation of cultural practices of both the individual region and the national cultural space in general. Moreover, modern Ukraine has a stable "transitional" dynamic, which can be defined in the categories of political scientist D. Rustow (Dankwart A. Rustow) $^{2}$ as a "transit society", that is, a post-period (postSoviet) society, which actively tries out new social and cultural practices, choosing transformational ways of overcoming the rudiments of old system (economical, political, cultural, artistic, administrative, valuable, etc.), creating a "new consensus", new stability. Moreover, one of the prominent factors of such stability is the comprehension of the value of national unity in the system of local peculiarities in a multicultural environment. Accordingly, Ukrainian society, as a society of high social and cultural dynamics in spatial discourse, is marked with a frontier characteristic, and culture is defined as a frontier, which is characterized by a "boundary".

Let us define the conceptual content of the basic concepts of local cultural studies - locus, topos (and the chronotope derived from it), region, cultural area, defining the subject plane of their application and semantic intersections. As it was noted by G. Hegel (who created and substantiated his own topographic model of the vertical - the ascent to the Absolute Spirit) notions-concepts arise when what they characterize disappears, goes to

2 Dankwart A. Rustow. Режим доступу: https://www.google.com/search?sxsrf= ACYBGNSbin417EMYEDjjSUaHbDp2vRigtA\%3A1577999733715\&ei=dV0OXviZK-34qwG4gYXg DQ\&q=Dankwart+\%D0\%90.+Rustow\&oq=Dankwart+\%D0\%90.+Rustow\&gs_l=psy-ab.3..33i16012. 35052.35052..35542...0.3..0.165.165.0j1..........2j1..gws-wiz......0i71.75LrUr4NcfM\&ved=0ah UKEwi4qNWM6-XmAhVt_CoKHbhAAdwQ4dUDCAs\&uact=5 
completion. According to this logic, it is possible to determine cultural area only from the standpoint of a certain design of integrity in the tension of "holding" the local as, on the one hand, the instant-ontological (that Heideggerian "daylight" of being), and on the other - changing and dynamical, constantly changing, flowing (but not in time categories, but spatial boundary/boundaries). The conceptual revision of the concept of "cultural region" should also be based on the latest methodological approaches based on the idea of the spaciousness of cultural phenomena and the dynamics of regional formation in historical aspect and modern perspective.

The cultural region is a territorial formation with its own characteristics and features of development from the standpoint of the classical definition. In the history of cultural thought, the concept of the cultural region was formed on geographical, natural and climatic differences; and the outlook constants of the regional identity carriers - on traditions, myths, religion, language, monumental architecture - all that O. Spengler called "physiognomy of culture" ${ }^{3}$.

In the context of non-classical humanities, the cultural region can no longer be determined by cartographic, ethnic and landscape parameters. Modern cultural studies actively produce ideas of opposites, discrepancies between the spatial and topological dimensions of culture and their ontological foundations: for example, culture of national diasporas, discrepancies of locus of residence and locus of labor (Ukrainian guest workers), transcultural interactions of extralocal certainty (Internet space), emigration, multicultural art and artistic space - all these phenomena and processes (which can be called "spatial compression") only confirm the idea of the complex structure of modern regional formation.

Moreover, it is necessary to distinguish geographical area (territory) from cultural (place). In other words, culture not only marks the place but also produces it $(\mathrm{H}$. Lefebvre). It is in sociocultural interaction that cultural locations - loci - are created.

Therefore, local dimensions of the typology of cultures, in which an alternative to national and regional distribution is actualized: the atomic integrity of locality forms the uniqueness of a particular community as a unitorganism (like the model of uniqueness of the "soul" of each O. Spengler culture). Thus in the local discourse there is a "meeting", the interaction of such permanent cultural characteristics as "picture of the world",

3 О. Шпенглер про історичної типології світової культури. Режим доступу: https://studme.com.ua/129312224872/kulturologiya/shpengler_istoricheskoy_tipologii_mirovoy_ kultury.htm 
"worldview", "mentality" with the dynamics of historical and cultural realities, geopolitical situations, frontal gaps and dialogue. The cultural knowledge in the methodology of locality creates a theoretical plane for exploring one of the possible scenarios for describtion of culture as a holistic object.

We analyze the content and correlation of topological terminology in the context of the study of regional identity in cultural polymethodology and cultural and historical relevance.

The locality within established boundaries-intersections is a topos (from ancient Greek $\tau$ o $\pi$ o $\varsigma$ place) - how can one think of a cultural region without imagining the area it occupies? But in ancient Greek, topos is not only a certain place on Earth (country, locality). This word means universality of location - it is a place on a page of a book and a place in a human body, etc.

For a more precise definition of topological terminology in the context of ancient Greek tradition, let us refer to the texts of M. Heidegger, for whom, as we know, language (most of all ancient Greek language) was a special landscape, in which philosophical meanings were hidden. Thus, M. Heidegger noted that Aristotle for the first time explicitly formulated the meaning of the word "space" and thereby set a cross-cutting tradition for further theoretical destiny of its interpretation. Aristotle's first definition is this: $\tau$ ó $\pi$ o $\varsigma=$ place (Ort) (the Greeks did not have their own word for the concept of space at all); the place of the body was determined by the fact that what it limits as a burden. At the same time, for the Greeks, the border is not where something stops, not negative, but what starts something, what forms, sets the borders. The border $(\pi \dot{\varepsilon} \rho \alpha \varsigma)$ is a positive definition for the Greeks. The other thing that allows something like an extended bodily thing to occupy space is called by the Greeks $\chi \omega ́ \rho \alpha$ : a space that can accommodate such a limited thing. Space has the property of accommodation, it gives things its place; space encompasses that one, which is outlined by the boundary of the bodily thing and which is offered by the space itself".

Utopias are the first variant of speculative reflections-concepts regarding topology-locality. Utopia is a fictional place, a place, which does not exist, a place-myth. In the context of spatial modality, utopia can also be defined as the space of the imaginary, the space of the symbolic, the ideal. The opposite of the concept of utopia is the concept of heterotopia ${ }^{4}$. This explains the true renaissance of utopias in the Renaissance (F. Bacon, T. More, T. Campanella), when for the first time with the discovery of infinity, a person could allow to

\footnotetext{
${ }^{4}$ У науковому дискурсі існує ще один варіант топосу - ізотопія - об’ єднання смислів (або пошук) в одному культурному просторі. В методологічному ракурсі - це формулювання загальних рис культури на різних рівнях його розгортання.
} 
construct social space in the categories of "topographic" rather than in categories of "ideal" (as it was from Plato). Herefrom is the powerful movement of discoveries (or "rediscoveries") of new lands, the New World. Accordingly, topographic characteristics are actively involved in European rationality as a factor in modeling of local identities (city, district, country, nation, continent, etc.).

Heterotopia (from the ancient "other place") is the transfer of a cultural locus from the place of its "production" to another cultural space. In the context of our study, the creation of a model of cultural locus as a production of space of general meanings without rooting them in one place-topos. Any culture is heterotopic in its nature. Therefore, this characteristic creates the necessary research aspect to understand the variants of cultural "transfer", "overflow", "avoidance". Non-classical humanities actualized the concept of heterotopias: M. Foucault ${ }^{5}$ developed this principle in his own model of disciplinary loci. French philosopher singled out four models of heterotopia in culture. The first model is the model of crisis and (or) deviant heterotopias - spaces, which place people who do not fit into the parameters of the "normal" place (for example, in traditional communities for women in their reproductive functions); in modern cultures (in the context of cultural Foucault concepts) there are so-called "disciplinary spaces" (recreational homes, prisons, homes for the elderly, clinics, hospitals, etc.) which are localized through the existence of models of certain discursive practices. In the categories of cultural regions, this is any model of closed recreational space, museum, archive (for example, museums of folk life and crafts, in which the modern man "simulates" folk crafts, producing them in a museum environment).

The second model of heterotopy is a model of configuration change of a place depending on change in a sense of culture. Foucault gives an example of the location of cemeteries in the European tradition: cemeteries near the church in central locations of the area are gradually being transferred outside the city, on the outskirts, on the line of delimitation (city/non-city), creating in the present such parallel "settlements", "twin cities". In the categories of cultural regions, this model of heterotopia clarifies the principle of synchrony of sacred spaces (from sacralization to oblivion and conversely).

The third model is a combination of several cultural loci-places in one topos. For example, an auditorium in a cinema is a combination of theater art tradition with a three-dimensional, two-dimensional screen-canvas. In the categories of cultural region, for example, it is the main square of any city (for example, Kiev "Independence Square"), which unites different cultural meanings - the center, the place of fateful events, symbol, title, holiday, etc.

${ }^{5}$ М. Фуко Режим доступу: https://uk.wikipedia.org/wiki/ Мішель_Фуко 
The fourth model is a model of a sense change of a place due to a severance with traditional time (a kind of "time machine" transferring from one time to another within one locus). In categories of region, these are the loci of the holiday (for example, City Days, fairs, festivals): places which for some time "cut off" the holiday into everyday life. No wonder that any festival movement begins with definition of a good location (castle, square, historical house, etc.).

Therefore, as it was noted earlier, the essence of any culture is determined by its degree of heterotopicity. The romantic metaphor of this cultural characteristic is, according to Foucault's ${ }^{6}$ suitable definition, a floating ship: a ship (culture - auth.) is a certain locus of concentrated senses that travels, moving across the boundless ocean from one port to another in search of treasure and the unknown. Heterotopia "nourishes" cultures. "Otherwise, in civilizations without ships (see without heterotopia - auth.) dreams fade away, adventures give way to espionage, and corsairs become police".

In the context of the study of local parameters of national culture of Ukraine (Western Polissya), these models contribute to the analysis of localities of both positive and negative heterotopias. It is the local dimensions of national culture that make it possible to understand the ways, in which cultural meanings are generated by the "place" (not territory) to find the boundaries of tolerance/ intolerance, susceptibility/insusceptibility, openness/closedness within both local culture and national identity. Heterotopia actively forms the artistic and artistic space. The principle of heterotopy allows to present a model of living of traditional art (in the version of folklore) in modern amateur art. Seasonal festive areas of local festivals can also be explained in the heterotopic intersection models - the meeting of the festive and the everyday, creating the event model of a holiday festival.

In the history of cultural thought, two general vectors for defining culture can be identified from the point of view of its local characteristics. The first line is the so-called conceptions of local cultures, which appear as opposed to the Eurocentric paradigm of universal cultural and historical linearity (Baden Neo-Kantian School, O. Spengler, A. Toynbee, A. Kreber). Another vector, the opposite one, in theoretical models of which culture is always a supersystem phenomenon, which combines linguistic, social and organizational, technological, valuable parameters and elements. Accordingly, typological diversity does not appear at the level of individual cultural formations (loci), but in the variant of new combinations, interactions (L. White, K. Levy-Strauss, evolutionists). In this context, we recall the work of a famous French social philosopher A. Lefebvre, with the eloquent name

\footnotetext{
${ }^{6}$ Там само
} 
"Space production", in which the thinker raised the need to designate social space not only as a static marker of place, but as an interactive factor of production: "it's a product-producer, support of economic and social relations. It is possible that the cultural space is involved in the process of reproduction of the production mechanism, in the creation of branched social connections, which are realized in practice "in the locality". The space-locus forms societies, institutions, social and cultural practices and also generates artistic forms, which are considered in this dissertation in unity and interaction.

Therefore, local culture (Lat. lokalis - local, locus - place) is something that belongs to a particular place, creating a separate cultural location. Moreover, the sub-nationality of local culture is not constructed as a relation of "a part to the whole" (the sum of local cultures cannot determine the national cultural whole). Accordingly, the problem of the study of Ukrainian local cultures is in the permanent uncertainty of the state borders, their discrepancy between cultural loci. In the conditions of modern multi-ethnicity of any state formation (and Ukraine in this matter is no exception), unification takes place on fundamentally different parameters: social and cultural identity, political and economic interests. Modern state formation strengthens the discourse of local cultures, directing imperia and centralized intentions into a vertical model of the intersections of individual cultural loci. In general, within one national state the formation of cultural locations is influenced: the state administration creates or cancels certain administrative and territorial units, transfers the capital cities and so on.

In most European countries, the strength and dignity of a national state is not determined by the longevity of its existence - local histories influence the formation of national discourse, not conversely. For example, in France, the influence of regions is growing in proportion to their distance from the capital: almost all modern Bretons believe that "first Brittany and then France". In this perspective, F. Brodel explored the local features of the French as separate loci-worlds with mental uniqueness, outlook, worldview and life. F. Brodel also incorporates a discourse of gastronomic features and preferences into the structure of cultural uniqueness, in which food is also transformed into a regional marker of identities.

In the same way, more and more actively the locality becomes not only a sign of cultural identity, but also partly a way of survival. Probably, for the contemporary Ukrainian culture, the model of regional identities should be formed as polylocal discourse, the atomicity of which can serve not as an artificial (not "from above", not from the center determined) model of cultural integrity, but a rod (axial, according to K. Jaspers) with an externally forming system. Moreover, the conceptualisation of local discourse at different levels - mythological, historical, political and ideological, aesthetical and artistic creates (forms) the integrity as a model of cultural area. 


\section{Local Content of Analysis: The Specificity of Research Strategies}

Based on the premise that the local cultural space, as a dynamic and complex phenomenon, is a component of the universal cultural locus and requires in the process of its research the emphasis on all components, which allow it to be studied in its entirety, taking into account various objective and subjective factors, the study pays attention to all directions and approaches, which make it possible to study this phenomenon, combining local lore, historical, cultural, social and cultural, artistic discourses and comparative definition of models of their interaction.

The local text is understood as a cultural concept, in which vertically correlate cultural components around a particular axis - the axis of a particular cultural region. This approach causes the transfer of topographic definitions of culture (culture as a locality, cultural and historical plane) into the realm of ontologically semantic formulations (loci of being). This difference is perfectly "responded" by language: if the phrase "cultural space" is freely converted into a phrase "intercultural space", "multicultural space", etc., then the finality of "local" can not be "overlapped" by the "inter-", "poly-", but only in a different locality. For this difference you can "check" and the concept of "region". It should also be considered, that the concept of "region" within modern social and cultural studies is becoming a construct, an object of political and ideological technology (for example, the creation of discourse "South-East" by Russian political technologists in relation to certain regions of Ukraine; "North-South" in the US Civil War, etc.).

In cultural studies, along with the concept "cultural space" (often needlessly synonymous), the concept "cultural landscape" is used. The difference between these two is that the cultural landscape "binds" the culture to geographical spatial configurations (place on the plane), and the cultural space is the extent "vertical/horizontal" of the culture, a constant combination of place and cultural meanings.

It is necessary to clarify in this context the meaning of the concept "cultural locus". Thus, the "cultural locus" is a bifurcation of the uniqueness of a certain place-point in the dynamics of creating cultural connections and meanings. The synergy of place-point (locus) creates conditions (including spatial) to attract cultural meanings, organizing the polysystem model - the cultural locus.

To better illustrate the mechanism for creating cultural locality (and to more accurately identify the differences between different types of spatial definitions of cultural identity, such as "cultural space" and "cultural landscape"), we include in our research circle the concept of "chora", by which we can clarify some methodological positions of local discourse in cultural studies. 
The notion of "chora" (from ancient Greek X'́p $\alpha$ - country, land, place) ${ }^{7}$ in the ancient Greeks, as it was noted above, was used alongside the term "topos." Deconstructivists recalled this synonym dyad - topos/chora and implicate in scientific circulation to distinguish the practices of speaking and writing (to call into question the logocentric world regulation as a basis for the New European cultural tradition with all its components). Thus, J. Derrida transforms an underused concept into a general concept of his own methodology. Involving Plato's "Timaeus" dialogue, the word of the chora is tested by a French philosopher on models of a place, which cannot be determined, established, "grasped", but which generates and accumulates meanings (models of identification).

Thus, for Socrates in this dialogue of Plato, in order to explain own placehypostasis in the Athenian polis, it was necessary to choose a certain leveling position " beyond ...", "over ...", which Plato called the word "chora." Derrida developed this idea by presenting it as a model of the repository of "zero" meaning, as a "zero" place, which is capable of "receiving" and accumulating the following future meanings [4; 167]. A sort of apophatic definition of space ("space without space"), but with a subsequent heuristic of local certainty. By the way, the ancient Greeks' chora had another semantic basis - the so-called separate area in the polis system - suburbs, agricultural abutting lands, which are known to be a part of cities-states. Negative spaciousness is also explored in the semiotic model of Yu. Krysteva, for whom the concept of chorus is a pre-eminent way of expression the meanings (the same unformed design, background text, maternal speech).

Fitting into the polymethodology of non-classical humanities, the concept of "chora" becomes an auxiliary construct to express negative locality, locality without place, locality in the bifurcation number of future systems' creation (cultural loci).

Thus, a comparative approach in the study of the specific relation of the concept of locus with other models of topographic definition of culture (region, topos, local cultural space, local text, local myth, etc.) allows to trace the formation order of the original features of locality. So the local culture is formed:

- as a model of a particular type of culture - ethnic, traditional;

- as a model of regional determination - geographical, political, economic;

- as a model of dynamics in time - historical;

- as a model of life originality - artistic practices from the standpoint of their formation and institutionalization.

${ }^{7}$ Вайсман А. Д. Греческо-русский словарь: репринт V изд. 1899 г. Москва : Греколатинский кабинет Ю. А. Шичалина, 1991. С. 1307. 
Accordingly, the concept of a cultural locus may contain a complex of concepts-characteristics of particular cultural spaces - artistic, symbolic, imaginary, communicative, everyday, etc. That is, different areas of cultural life are reproduced in different temporal and spatial forms of its creation. Moreover, the local text is at the same time a text of culture, which is "decorated" with powerful aesthetic and artistic means, artistic practices, artistic policy, artistic education, the activity of individual representatives of both professional and amateur artistic fields. This is the conceptual basis of the research - to identify and analyze the shaping and institutional processes of a particular cultural region in the national space of Ukraine - Western Polissya - in models of the vertical axis, which are "strung together" by unique local meanings, value propositions, modes of representation, memory loci, personal modes of aesthetic and artistic activity. The local context actualizes the problem of the importance of individual experience, which cannot prevent the existence of formal boundaries. Topological discourse enhances the existential dimension of local human identity - the selfidentifying marker "who am I?" is identified with the spatial marker "where am I from?". Biographical and memorial research within local histories is a must have program for any mobile community: belonging to a particular place is not always determined by cultural affiliation; local stories vary and change at different moments in life.

The same happened in the Polissya-Volyn region, when with the transition of lands to the USSR the local discourse changed dramatically, combining imperial-Soviet semantics with local peculiarities. Accordingly, the ways of constructing the meaning also changed and the socio-cultural process of institutionalizing the cultural practices, which we were exploring, was also consistent with this. Technology and processing of social and political change has its own patterns; and artistic culture becomes a necessary tool for influencing these changes. The mental-root layer of culture, of course, changes much more slowly and less radically.

Local myth is a necessary component of the local identities formation. The modern myth is created with the help of historical memory. It is the specificity of cultural memory, together with the techniques of remembering, forgetting and memory places, that transforms history, the narrative about the past into the imaginary story, which, in fact, becomes a myth. It should be considered, that the mythologization of the locus is the final stage of creating a local cultural identity. And not with a mythology begins an identity, but with an exit to the "other." First, the plane should be shaped, acquire a stable boundary and consolidate the centralization and repeatability. Then stability and firmness of interactions lead to self-awareness of location as a uniqueness, which is usually made possible by the external observer (in the 
methodology of "dialogue of cultures" it is a period of enrichment of cultural meanings due to the distance-limit of looking at oneself as at another one). The next stage is the stage of mythologization of unique traits, search and presentation of identity in different forms of cultural practices. For example, a myth of place is a technology of remembering, which is actively used in modern representational forms (including in artistic practice). In this perspective, art also arises as a powerful factor in the representation of identity.

Considering that historical knowledge appears in the nineteenth century (as well as cultural studies), and continues to formulate approaches and principles for the representation of the past, it is necessary to constantly take into account the complexity of such obviousness as "cultural history", which, on the one hand, arises as a range of cultural studies and, on the other, is saturated with methodologies of historical knowledge. Local history is one of the areas, which equates traditional academic principles of historical science and models of non-classical cognition in the categories of local narrative as discourses of cultural anthropologists, historical geographers, sociologists, demographers, urbanists, etc.

One of the modern models of spatial locality representation and study is the microhistory model, which appeared as a methodological construct in comparing official scientific historical knowledge and models of historical representation as amateurism of local histories and chronicler speakers without the status of historians, who from the positions of meta-narratives were automatically included in the category of "non-speaking majority" (by A. Gurevich). Although A. Gurevich formulated this maxim as a methodological principle of understanding the culture of the European Middle Ages from the point of view of alternative written sources of research positions $^{8}$, the same hierarchy of representation does not disappear even at the time of total fixation of "stories about anything". For example, one of the monographs of a famous British scientist and historian S. Fowler (Simon Fowler) represents the culture of the "non-speaking majority" as early as the nineteenth century, exploring the lives, everyday life and mentality of workers who lived in the so-called "working houses". This cultural locality reflects a powerful layer of misery history as an alternative to the cultures of elite palaces, philosophers' offices and writers, science labs and university departments. And in this type of intelligence there is a need and a necessity, since the principle of "non-speaking" is not in the foreground of the fact of source fixation. In the context of the study of atomic cultural loci only the

\footnotetext{
${ }^{8}$ Паралельно таку ж історичну ревізію проробляв М. Фуко в генеалогіях влади знання новоєвропейської епістеми
} 
research point-position and scaling change. And such a controversial replacement does not affect the value of the achieved results in any way. On the contrary, micro-narratives form the semantic lacuna of local cultures as a discursive plane of "new locality". The contrast (rather conflict) of academic history and local lore (local lore, which in most cases, unfortunately, continues to be a research realm of amateur historians) should end in the formulation of local narratives in institutional arrays and scientific legitimization. There are eloquent examples of such completion.

For example, in the English-speaking scientific tradition, the term "local history" is used to represent a particular branch of historical knowledge from the standpoint of particular unrelated localities - the history of a particular city or village, home, building, local cultural industries and organizations, individual residents and families on the background of local traditions, customs, folklore and popular culture. Moreover, communities are initiating and creating powerful research and information platforms, where every interested person can find what he needs to understand and (what is more valuable) create his own local narrative. The Ancestry Library's online archive search programs are being created and operating, so-called "local offices" are being developed - the collections of local history information, which, unlike traditional local history museums, tells history on behalf of an individual. In other words, the simplicity and intelligibility of the term "local history" actually conceal the complicated vicissitudes of humanitarian knowledge of the present, in search of new approaches to the representation of the historical past beyond the meta-hierarchy of meanings.

Modern urban studies convincingly test the principle of local discourse. The methodological approaches of urban studies make it possible to present urban culture as an extremely important concentrated locality with a wide variety of cultural practices. And the city as a system is a construct, which needs to be modeled from the standpoint of environmental friendliness and harmonization of all its components. The theoretical substantiation of these positions is presented in the works of M. Weber, B. Groys, G. Simmel, M. Castels, L. Mumford, A. Turnen.

For our study, urban locality (in the image of such cultural centers of the region as Lutsk and Rivne) is considered not only from the standpoint of their unique historical and cultural characteristics and peculiarities of the formation of creative and artistic centers and cultural and artistic practices. The study of the cultural potential of urban space in Lutsk and Rivne is an example of the creation of a methodological basis in the dialogue between ethno-localities and the state (or states). As it was demonstrated by the potential of this type of understanding, a modern Finnish anthropologist and sociologist A. Turunen proved in the book "Forgotten History of Cities: How Wealth and Cultural 
Development Are Acquired by Tolerance", that the cultural progress of cities provides one, but overriding characteristic - tolerance. On the example of world cultural centers (such as Miletus, Alexandria, Florence, Amsterdam), he notes that all cultural innovations (economic, cultural and artistic) arise in a condition of tolerant community attitude to various opinions and reveals (even extravagant and arrogant). According to the model of modern urban design of urban spaces - it is, first of all, models for creating spaces for communication and deliberate experimentation with the "other". To the extent that this approach is fully implemented, the city is capable of forming its own cultural capital. It is not without reason that, together with urban experiments, the festival movement, educational and artistic space and cultural infrastructure are activated. In other words, these institutional shifts and changes in the context of urban science are always consequential factors of multicultural synthesis. This approach is at odds with the usual so-called "container" theory according to which cities are viewed from the standpoint of national states formation.

The "boundary" status of Western Polissya is a starting factor for considering cultural and artistic processes of region in our study. The principle of dialogue between the cities of Rivne and Lutsk in the creation of local identity allows us to create a dynamic model of local spaces, within which transformational processes occur, which is the purpose and object of this work.

This study can serve as an example of the creation of such "local cabinets": the cultural processes of region under study are reconstructed on the basis of rich factual and personal material, which gathered and analyzed all significant cultural and artistic phenomena as distinctive factors of local cultural formation of Western Polissya. At least such a variety of material is converted to a structured model in a vertical axial projection. Artistic practices (both professional and amateur), art-educational institutions and management strategies, representative forms of local cultural features (exhibition activity, festival movement, photo-, cinema representations, local amateur artistic creativity) - these are the components of the cultural locus collected and explored in such a multilayered combination.

In addition to the "axial" methodology, the principle of meaningful distinction between "culture" and "cultures" is involved. The versatility "culture" in the context of the study of models of local cultural practices dialogues with the multiplicity of cultural forms (art, amateur art, crafts, art education, practice of management structures, press, Internet content, photography, cinema, television, art exhibitions and festival movement).

The ascending principle of the multiplicity of "cultures" as forms of cultural practices is their institutionalization: individual cultural reveals are 
seen as social institutions; and their activity creates a distinctive system of culture in region. Hence the logic of meaningful "branching" of various forms of artistic practices is being built: the institutionalization of folk traditions (amateur creativity, decorative and consumer dimensions of popular initiative); Western Polissya art practice as a representative form of identity in the creation of a local cultural and artistic space (musical life, photography, film art, painting, exhibition activity); managerial technologies and educational strategies in the formation of local cultural characteristics of Western Polissya (formation and development of art education in region, experimental models of leisure forms, some aspects of management of organizational and financial and methodological support of artistic practices) and peculiarities of organizing and conducting regional festivals ("Art Jazz Cooperation", "On the waves of Svityaz' lake". Moreover, the regional identity is built up through intra-local characteristics (ethnic, historical, denominational, political, social, cultural, etc.), and in comparative comparisons with other cultural topos in the context of the overall national space of Ukraine. The algorithms of local cultural practices in the aspect of the institutionalization of the artistic space (art education, leisure forms, local festivals, amateurism) create a "local cultural code".

The UN report on cultural development as an extension of cultural practices provides the following classification of the creative economy: 1) cultural heritage, 2) visual and performing arts, 3) audiovisual branches, 4) Internet and printed media, 5) the latest media; 6) creative services (advertising, design, architecture). All these directions are factors of contemporary cultural formation, and their interaction is a dynamic plane of specific cultural practices. According to this classification, all our publications analyze local cultural and artistic practices as a multidimensional process, which is characterized by the involvement of political, economic, social factors, artistic and educational strategies, activism of the civil sector (individual representatives of the artistic elite of the region) and stateadministrative strategies. Without pretending to be exhaustive of this material, we understand that this "encyclopedic" variety of research can serve future research and to the next scientists, specifying in individual subject aspects and methodological approaches. We have deliberately chosen such a unifying (synthetic) model because it is important to present diversity as a synergistic self-movement of local forms and processes in contemporary local cultural formation.

\section{CONCLUSION}

So the spatial discourse in the context of contemporary cultural studies is determined by the search for a "new locality" as a way of constructing a 
cultural map of processes and phenomena, which are actively changing and transforming. Therefore, the discourse of "local" in culture and local cultural phenomena in the national space become a research unit in the study of the features of contemporary cultural, artistic, educational, managerial or various leisure practices, the dynamic of which creates the appropriate synergy of the polysystemic model.

Attention is drawn to the concepts of spatial discourse in the context of contemporary cultural studies, which are also defined by the search for a "new locality" as a way of constructing a cultural map of processes and phenomena, which are actively changing and transforming.

Understanding this semantic instability within the limits of cultural science, the author analyzes the content and principles of spatial definitions of culture, in particular: locus, topos, chora, heterotopia, cultural space, cultural locus, frontier, etc.

Western Polissya is a specific Western Ukrainian cultural locus, which covers the territory of Rivne and Volyn regions.

The scale of the local cultural features study is also changing: the national is no longer a permanent generalizing and metaphysical combination of localities. Accordingly, the cultural locus in frontal dynamics can change the markers of the general (national) and single (local) markers to the opposite. For example, as Western Polissya is not the sum of the cultures of Rivne and Volyn regions, but is a distinctive locus of national culture, so Rivne and Volyn regions form a national cultural discourse with their local cultural formation.

\section{SUMMARY}

The processes of globalization, which until recent times were considered without alternative and dominant regularity of civilization concede, are balanced by the tendency to structure and differentiate the world cultural space today. In such circumstances, individual cultural locations arise in historical structures, which form the basis of human communication in all times of history and consolidate its ontology with the value energy of ideas.

The materials of the section review the specificity of local detection in modern cultural knowledge. The analysis of scientific works of leading western researchers, for whom these issues are of interest, is accomplished. Attention is drawn to a number of concepts, such as "cultural region", "topos", "locus", etc., and their modern interpretation is given. An attempt was made to identify models of heterotopy (from ancient Greek - place). The specificity and the role of region in the Western European context is clarified and the methodology is applied to the Ukrainian context, including Western Polissya. Leading local culture models were identified. 


\section{REFERENCE}

1. Gurevich A. Ya [1990]. Srednevekovuj myr y kuljtura bezmolvstvujushhegho boljshynstva [The medieval world and the culture of the silent majority]. Moscow: Art. p. 396.

2. Derrida J. [1998] Esse ob ymeny / Per. s fr. N. A. Shmatko. Moskva: Yn-t eksperymentaljnoj socyologhyy; Spb. : Aletejja [Essay about the name / Transl. from French N.A. Shmatko. Moscow: Institute of Experimental Sociology]; SPb : Aletheya. pp. 137-192.

3. Lefebvre A. [2015] Proyzvodstvo prostranstva / Per. s fr. Moskva. [Space Production / Trans. from French. Moscow]: Strelka Press. p. 432.

4. Foucault M. [2006] Drughye prostranstva. Yntellektual y vlastj: [Other spaces. Intellectual and Power: Selected political articles, speeches and interviews / Trans. from French B. M. Skuratov under gen. ed. V. P. Bolshakova]. Moscow: Praxis. ch 3. pp. 191-204.

5. Heidegger M. Collykonovskye semynaru [Tsollikonovsky seminars / Transl. from German. I. Glukhova]. Vilnius: EHU, 2012. p. 406.

6. Fowler Simon [2014]. The stories of those who lived in the shadow of the workhouse: The People, The Places, The Life Behind Doors. Pen \& Sword History.

\section{Information about the author:}

Vytkalov Sergiy, Doctor of Cultural Studies, Professor of the Department of Cultural Studies and Museum Studies

Rivne State Humanitarian University 12, Bandera str., 33028, Rivne, Ukraine ORCID ID: orcid.org/00-01-6362-9517 